POLYGYNOUS MUSLIM MARRIAGES IN SOUTH AFRICA: THEIR POTENTIAL IMPACT ON THE INCIDENCE OF HIVIAIDS

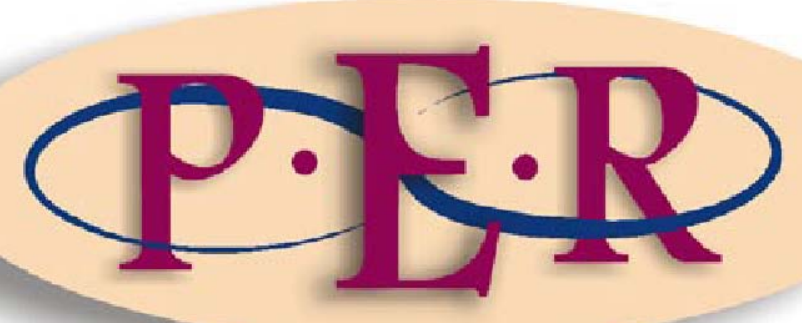

2009 VOLUME 12 No 3 


\title{
POLYGYNOUS MUSLIM MARRIAGES IN SOUTH AFRICA: THEIR POTENTIAL IMPACT ON THE INCIDENCE OF HIVIAIDS
}

N Moosa*

\begin{abstract}
Only very rarely in human history does the advent of a single... phenomenon so fundamentally impact upon an entire civilisation so as to cause it to re-examine and reformulate its basic assumptions as to its destiny, to review both its instinctive and articulated ethical assumptions, to restructure its productive processes and concomitantly and inevitably to reformulate its legal premises...The HIV epidemic is potentially...such a phenomenon... ${ }^{1}$
\end{abstract}

\section{Introduction}

Polygyny $^{2}$ is generally deemed to be incompatible with Western ${ }^{3}$ norms of monogamy and equality, and, therefore, discriminatory to women. This article does not debate the merits and demerits of this view, but proceeds from the premise that polygyny as a religious and customary institution, although not commonly practised in South Africa, is recognised both in Islam as religion and in South Africa. Furthermore, given our historical, political and cultural context, it is not surprising that the State has, with a democratic dispensation in place, given full legislative recognition to polygynous African customary marriages, ${ }^{4}$ and is in the process of doing so for Muslim religious marriages.

* $\quad$ Former Dean, Faculty of Law, University of the Western Cape, Bellville, South Africa. This article started out as a co-authored joint venture with Mr Armien Cassiem (formerly of the University of the Western Cape). It has subsequently been completely refocused and revised by the current author who would like to acknowledge the initial contribution of $\mathrm{Mr}$ Cassiem. This article is based on a paper that was presented at the Inaugural Conference of the Centre for Responsibilities, Rights and the Law on Gender, Family Responsibility and Legal Change, hosted by the Sussex Law School, University of Sussex, United Kingdom, held on 10-12 July 2008. The author would like to thank Professors I Leeman (University of the Western Cape) and Z Motala (Howard University, Washington, DC, and Extraordinary Professor, University of the Western Cape) for their editorial assistance in preparing this article.

1 Mahomed 1993 SAJHR vi.

2 By way of elucidation, polygyny refers to a plurality of wives while polyandry refers to a plurality of husbands. Although polygamy is a gender neutral and generic expression covering both institutions, only polygyny is permissible by Muslim law, and hence the use of this term.

3 This does not preclude its practice in the West by, for example, amongst Mormons in the USA where polygyny is a crime.

4 Polygyny in South Africa was generally not illegal provided it was practised by Black Africans in the context of a customary marriage (which had partial legal recognition), with 
HIVIAIDS $^{5}$ is a modern epidemic and introduces new debates in religious and interfaith discussions. Although treatable, it is to date incurable. While AIDS was first recognised in 1981 as a mainly homosexual problem in the USA, it has since then increasingly become a heterosexual problem, as is also the case in South Africa. HIVIAIDS does not discriminate, and no person (regardless of sex, class, race or religion) or region in the world (including Muslim countries) is immune from it. The first cases of AIDS were identified in South Africa in $1982 .{ }^{6}$ Today, two and a half decades later, and arguably because of the inertia of the previous apartheid government and mismanagement by the current democratic government, South Africa is "...regarded as having the most severe HIV epidemic in the world" ${ }^{7}$ and

more than one in eight people [are HIV-positive]. Some eight hundred South Africans die of AIDS on an average day. And the epidemic is spreading at a rate of more than a thousand new infections a day. ${ }^{8}$

Muslims are expected to observe a strict moral code of conduct. There is the misguided perception that HIVIAIDS has largely bypassed Muslims because Islam forbids homosexuality and promiscuity. This article examines whether there is any relationship between the institution of polygynous marriages in Islam and the spread of HIVIAIDS. Campaigners against HIV, adopting a health

special courts giving effect to its consequences. However, civil courts were reluctant to recognise such marriages as legal marriages (Dlamini 1989 CILSA 330 and 342; Kaganas and Murray 1991 Acta Juridica 133). Customary law in South Africa is the personal law of the majority of Black Africans who constitute the vast majority (over 35 million) of the total population (nearly 45 million). See s 4 below. The Recognition of Customary Marriages Act 120 of 1998 gives full recognition to customary marriages. The Act also gives full legal effect to existing and future polygynous marriages.

5 HIV refers to Human Immunodeficiency Virus - causative agent, invisible, no symptoms. The HIV virus that causes AIDS attacks the immune system in human beings, the body's defence against disease. Over time it damages the immune system so that it can no longer fight infections. Most people who are infected with HIV have a long period when they look and feel quite well. Many people do not even know that they are infected. AIDS refers to Acquired Immune Deficiency Syndrome - visible, symptoms. AIDS is the most advanced stage of HIV infection. An adult person is said to have AIDS when his or her CD4 cell count is 200 cells or less per cubic millimetre $(\mathrm{mm} 3)$ of blood or has a specifically defined clinical illness. This makes the immune system so weak that the patient develops serious illnesses. This usually happens some years after becoming infected with HIV. In this article the terms HIV and AIDS will be used interchangeably.

6 See Eba "Pandora's box" 19; Ahmed Positive Muslims i-ii and 8.

7 AIDS Foundation sa www.aids.org.za/hiv.htm. See also n 55 for statistics.

8 Steinberg Three-Letter Plague 2. 
and human rights approach, advocate and/or highlight that, compared to monogamy, polygyny either amplifies rates of HIV transmission or is the cause of its spread. Some of the general concerns raised highlight that states' legal condonation rather than discouragement of polygyny has the deleterious effect of perpetuating inequality within marriage; contravenes provisions in international instruments; results in a violation of women's sexual and reproductive health and dignity; and negatively impacts on women's ability to insist on spousal fidelity or condom usage, negotiate their sexuality and choice in leaving such high risk relationships. While not detracting from the popularly held view that women in polygynous relationships may be at greater risk of contracting HIV than their counterparts in monogamous relationships, in briefly addressing some of the concerns raised, this article suggests that, while it may indeed be a contributing factor, it is not the institution of polygyny per se that relates to the disease's spread, but the conduct of the parties to the marriage relationship, whatever its nature (monogamous or polygynous).

The focus and thrust of this article lie with the institution of polygyny in Islam, the South African response to polygyny, the (potential) impact of polygyny on the incidence of AIDS, and the contribution that both an informed approach to HIV and an enlightened approach to the application of Islamic values, which I favour, could or would have on the limitation of the disease's spread. The article is structured accordingly.

\section{The Nature of Polygyny in Islam ${ }^{9}$}

Muslim Personal Law (MPL) ${ }^{10}$ pertains to, among other things, polygyny which

9 This S on polygyny is mainly extracted from a book written by the author (Moosa Unveiling the mind 40-45).

10 Henceforth the abbreviation MPL will be used. MPL derives from the primary sources of Islam, namely, the Qur'an (the holy book of Islam) and Sunna (traditions of Prophet Muhammad (Peace Be Upon Him)); hence the unwillingness to interfere with them. Sunna is received custom associated with Prophet Muhammad, embodied after his death in a body of texts compiled as books called Hadith. The salutation 'Peace Be Upon Him' will, for the sake of convenience, be implied but not repeated every time the Prophet's name is used in the text. 
falls under the category of family law. As far as marriage is concerned, Islam enjoins strict monogamy on women, and, furthermore, confines their choice of husband to the ranks of Islam. In contrast, a Muslim man may be married to as many as four wives at any one time, and these marriages can furthermore be mixed (inter-faith). ${ }^{11}$ Common reasons that are provided today by men in justification of the practice of polygyny, and some of which are supported by legislation in certain countries, customarily include, but are not limited to, infertility or long-term illness of the first wife, and excessive wealth on the part of the husband enabling him to support widowed or divorced mothers. ${ }^{12}$ This does not preclude women who have never married. In early Islam polygyny also served a useful socio-economic purpose in absorbing a surplus of women widowed by war, and several of the Prophet Muhammad's marriages were politically motivated. Islamic law allows women to include protective stipulations against polygyny in their marriage contracts which would entitle the wife to divorce her husband if he breaches them. ${ }^{13}$

Of the Prophet Muhammad's nine to eleven wives, only one was a virgin, whom he preferred and loved more deeply or differently than his other wives, and was, therefore, himself not able to treat his wives with absolute equality. This is acknowledged also in the Qur'an itself. ${ }^{14}$

While in the socio-economic context the Qur'anic polygyny verses can be quoted to show inequality between the sexes, there is scope in the primary sources to indicate that polygyny was not meant to be a permanent "reward" accorded to men, or a feature of Islam. Islam, via the Qur'an, in fact limited the practice of polygyny by men to four wives, ${ }^{15}$ with a strong directive towards

11 Q.2:221 and Q.5:5. In Qur'anic references the first figure is the number of the chapter or surah. The number following the separating colon indicates the verse or ayat. These references normally refer to the translation by Yusuf Ali (1946), unless otherwise indicated. See Ali The Holy Qur'an.

12 WLUML Knowing Our Rights 198.

13 See $s 4$ where the implications of divorce are further elaborated to indicate that such an option results in more hardship than relief.

14 Q.33:51.

15 Q.4:3. 
monogamy. ${ }^{16}$ Interesting to note is the fact that the relevant Qur'anic verse (4:3), although permitting polygyny, does so in the context of dealing compassionately with orphan-girls. This important fact, however, seems to have been of no, or little, consequence or relevance in the subsequent interpretations of these verses. The above-mentioned (polygyny) verses emphasise equal treatment among wives, but acknowledges that this is not possible, no matter how hard a man tries. ${ }^{17}$ An orthodox interpretation of these verses measures equal treatment in financial terms (relating to maintenance and housing, etc) with little, if any, regard to emotional and psychological effects.

It is not common knowledge that the Qur'anic verses limiting polygyny and exhorting monogamy were only revealed after Prophet Muhammad had married all his wives. In fact, the Prophet himself was prohibited by God in the Qur'an from contracting any more marriages. ${ }^{18}$ The Qur'anic verse prohibiting the Prophet from entering into any more marriages must not only be viewed as normative but indeed unique, in that God made provision for all eventualities, if Muslims are prepared to see it as such.

While Muslim activists of both sexes, like conservative Islamists and modernists, either support or reject the practice of polygyny, the bottom line is that, while reformers have tried to restrict polygyny within an Islamic framework, they find it very difficult to abolish it outright. All women and men, regardless of wealth and educational status, need, therefore, to co-operate in order to bring about change in family law. While certain countries have effected amendments or reforms to codes of personal laws, it must be noted that, on the basis of (the same) Qur'anic injunctions and intention, in some countries polygyny is

16 Q.4:129 and Q.33:4.

17 '...Marry women of your choice/ Two, or three, or four/ But if ye fear that ye shall not be able to deal justly (with them)/ Then only one...' (Q.4:3). 'Ye are never able to be fair and just as between women/ Even if it is your ardent desire...' (Q.4:129). 'God has not made for any man two hearts in his (one) body...' (Q.33:4).

18 'It is not lawful for thee (to marry more) women after this, nor to change them for (other) wives...' (Q.33:52) (emphasis added). After this verse was revealed in 7 Anno Hegirae $(\mathrm{AH})$ (or $628 \mathrm{AD}$ ), the Prophet did not marry again, except for having one concubine.

$69 / 161$ 
controlled by making it the exception and subject to judicial regulation (Pakistan), ${ }^{19}$ while in others (like Tunisia) ${ }^{20}$ it has been prohibited completely.

\section{The South African Response to Polygyny}

\subsection{Prior to 1994}

Moral disapproval of polygyny, and the fact that it was regarded as offending against public policy (contra bonos mores), resulted in Muslim marriages historically not being recognised by South African law. This was the case despite the fact that at the time "less than 2 per cent of the male Muslim population of South Africa ha[d] more than one wife", ${ }^{21}$ which proved that most Muslim marriages were in fact monogamous.

A valid civil marriage in South Africa had to be monogamous. This was quite clear from the context of our common law, statutes and case law, ${ }^{22}$ which show a clear bias towards western and Christian moral values despite South Africa being a multi-cultural and multi-faith society. ${ }^{23}$

Polygynous marriages, regardless of where they were contracted, ${ }^{24}$ were void in South African law, although they may have had certain legal consequences.

19 See s 6 of the Muslim Family Laws Ordinance of 1961.

20 See the Tunisian Law of Personal Status of 1956. By actually applying ijtihad (independent reasoning) it was possible for a country like Tunisia, for example, to outlaw and ban polygyny.

21 Ismail v Ismail 1983 (1) SA 1006 (A) at 1018A.

22 Ibid at 1021. See also Davids $v$ The Master 1983 (1) SA 458 (C). This approach may be traced back to as early as 1860 when the court in Brown v Fritz Brown's Executors (1860) 3 Searle 313 at 318) described an Islamic marriage as 'recognized concubinage'. For a detailed analysis of pre- and post-1994 South African case law relating to Muslim marriages, see Rautenbach, Goolam and Moosa "Constitutional analysis" 157-162. See also $\mathrm{n} 35$.

23 Moosa Analysis 352.

24 Kalla $v$ The Master 1995 (1) SA 261 (T). "Given the effects on women of non-recognition, the judgement in [this case at $270 \mathrm{G}-\mathrm{H}$ ] is...particularly cynical in citing an additional ground for the invalidity of Muslim marriages, namely that they do not comply with the constitutional need for gender equality" (Mbatha, Moosa and Bonthuys "Culture and religion" 162). "In holding that '... reliance upon s 14 (1) in [Chapter 3] of the [interim] Constitution to validate retrospectively a marriage which was legally valid (namely a marriage by Muslim rites which was potentially polygamous)...was misplaced' the court is continuing the legacy of the past" (Moosa (n 23) 392). 
Since the form of an Islamic marriage does not preclude further simultaneous marriage(s) by the husband, South African law regarded it as potentially polygynous, even if neither party had more than one partner, and even when the parties intended their marriage to be monogamous. Thus, a potentially polygynous union was equated with a de jure polygynous union. ${ }^{25}$ The status quo remained, although much progress was made towards the recognition of polygynous marriages since the end of apartheid and the adoption of the interim 1993 Constitution, ${ }^{26}$ with courts starting to recognise some of the effects of Muslim marriages in order to provide relief to women and children in cases of death or divorce. The human rights to freedom of religion and equality were, however, given equal weight in the interim Constitution, and this made it possible that Muslim marriages, once recognised, could be exempt from the Bill of Rights.

\subsection{4 to date}

The final Constitution appears to guarantee the right to freedom of religion ${ }^{27}$ to all South Africans, which entrenches the right to live according to the customs and traditions prescribed by those religions. The Constitution, therefore, lays the groundwork for the recognition and application of religious family law systems $^{28}$, but it does not constitutionalise the right to have any system of family law recognised by the State, so that religious groups still have to lobby for legislative recognition. The right to equality ${ }^{29}$ trumps the right to religious freedom, and this means that Muslim marriages, once recognised, will be subject to the Bill of Rights. ${ }^{30}$ The Bill of Rights, especially its equality clause, guarantees that the status of Muslim women in South Africa can be different, or better, than that of their counterparts elsewhere in the world. Provisions in international instruments which helped shape our Bill of Rights clearly call upon their signatories to eliminate discrimination against women in all matters

25 Ismail $v$ Ismail 1983 (1) SA 1006 (A) at 1020. See also Seedat's Executors $v$ the Master (Natal) 1917 AD 302 at 308 and Moosa Comparative Study 31-32.

26 Act 200 of 1993 (Interim Constitution).

$27 \quad \mathrm{~S} 15$

28 S 15 (3)(a)(i) and (ii).

$29 \mathrm{~S} 9$.

30 S 15 (3)(b). 
relating to marriage which, by implication, would include abolishing the practice of polygyny. South Africa has, for example, in 1995 ratified the United Nations document that embodies women's rights, namely, the Convention on the Elimination of All Forms of Discrimination Against Women (CEDAW), ${ }^{31}$ without any reservations. While its acceptance certainly marks an enormous step forward, it also has the limitations of all similar international instruments in so far as there is little power to demand its implementation. ${ }^{32}$

It has been stated that since 1994 there has been a change in the courts' approach to Muslim marriages. The content and meaning of the boni mores have, for example, been reinterpreted to accord with the new constitutional ethos of tolerance, pluralism and religious freedom.

Although no court has yet declared a Muslim marriage valid, and although they mostly refrain from expressing approval of polygyny, ${ }^{33}$ courts have given effect to some of the obligations arising from Muslim marriages. ${ }^{34}$

Nonetheless, legislative concessions and court interventions to redress the consequences of non-recognition have only provided partial relief.

The South African Law Reform Commission (SALRC), ${ }^{35}$ as the governmental body responsible for considering law reform, has examined the scope for

31 Art 16 (GA Res 34/180; 1979).

32 See Rautenbach, Goolam and Moosa (n 22) 171-172 and Mbatha, Moosa and Bonthuys (n 24) 164-167 for a critical analysis of the implications of international law on religious family laws in South Africa.

33 With the exception of Khan $v$ Khan 2005 (2) SA 272 (T) where the court extended recognition to polygynous marriages, but which judgement has yet to be confirmed by a higher court (Mbatha, Moosa and Bonthuys (n 24) 162 and 172).

34 Mbatha, Moosa and Bonthuys (n 24) 162. See, eg, Ryland v Edros 1997 (2) SA 690 (C); Amod v Multilateral Motor Vehicle Accidents Fund 1997 (12) BCLR 1716 (D); Amod v Multilateral Motor Vehicle Accidents Fund (Commissioner for Gender Equality Intervening) 1999 (4) SA 1319 (SCA); Daniels v Campbell 2003 (9) BCLR 969 (C); 2004 (7) BCLR 735 (CC); 2004 (5) SA 331 (CC). For a detailed analysis of some of these cases since 1994 see also Mbatha, Moosa and Bonthuys (n 24) 171-172. See also $n$ 22. That the courts are continuing to give effect to some obligations arising from Muslim marriages is evident from Hassam v Jacobs 2008 (4) SA 350 (C) and Hassam v Jacobs (with the Muslim Youth Movement of South Africa and the Women's Legal Centre Trust as Amici Curiae) Case CCT 83/08 (2009) ZACC 19. On 15 July 2009, the Constitutional Court decided that women who are party to a polygynous Muslim marriage are deemed spouses for the purpose of inheriting or claiming from estates where the deceased died intestate. The judgment arises from an application for confirmation of a declaration of constitutional invalidity made by the Western Cape High Court in 2008. See CC 2009 www.constitutionalcourt.org.za/site/Hassam.htm for the full media summary and judgment. 
recognition of MPL. A Draft Bill on Muslim Marriages (Draft Bill), ${ }^{36}$ contained in the 2003 Report, has been proposed to harmonise Muslim marriages and related matters with the Bill of Rights and its emphasis on equality.

Although polygyny is not widely practised in South Africa, nor encouraged amongst Muslims, ${ }^{37}$ and cognisant of the South African context, the Draft Bill envisages the recognition of all existing and future monogamous and polygynous Muslim marriages, subject to certain conditions. As a compromise attempt to create a balance between conservative and liberal views favouring and opposing polygyny, respectively, and still remaining true to the Constitution, clause 8 of the Draft Bill proposes that polygyny not be outlawed, but creatively curtailed in terms of complying with Qur'anic injunctions of justice, and that there be secular court intervention to prevent abuse. ${ }^{38}$

A secular court has to approve an application by a husband to take another wife. ${ }^{39}$ This approval will only be given if the husband can satisfy the court that he will be able to "maintain equality between his spouses," that is, treat his wives equally as required by the Qur'an, ${ }^{40}$ and that the financial consequences of all the marriages have been satisfactorily arranged. ${ }^{41}$ An existing spouse must be given notice of the intention to take a further wife. ${ }^{42}$ This is aimed at preventing the current situation, where existing wives are often unaware of a second marriage until after the fact. Failure to obtain the required court consent would render a husband liable to a fine of up to R20 $000 .{ }^{43}$ Unlike the case in

35 The South African Law Reform Commission Report on Islamic Marriages and Related Matters, Project 59 (July 2003), containing the background to the investigation by the SALRC, the names of members (which include the author) of the Project 59 Committee, the Discussion Paper 101 (published in December 2001) and Issue Paper 15 (published in May 2000), the extensive comments received from interested parties, and the final proposed Draft Bill on Muslim Marriages (appended as Annexure A in the Report), are available for public scrutiny at www.law.wits.ac.za/salc/salc.html. Ulama (religious leaders) were represented, and actively participated, in this process. See N 37.

SALRC 2003 www.law.wits.ac.za/salc/salc.html.

37 See 54.

$38 \mathrm{Cl} 8$.

$39 \mathrm{Cl} 8(6)$.

$40 \mathrm{Cl} 8(7)(\mathrm{a})$.

$41 \mathrm{Cl} 8(7)(\mathrm{b})$ and (c).

$42 \mathrm{Cl} 8(8)$.

$43 \mathrm{Cl}$ 8(11). 
some Muslim countries, like Pakistan, where the permission of the first wife is required, the Draft Bill requires the formal approval of the court. The position where there is one wife, would apply mutatis mutandis to a case where there are several wives. However, failure to obtain such approval, or his wife's permission for that matter, will not invalidate the husband's second marriage, and he merely has to pay a small fine - hardly a deterrent, as has proved to be the case in Pakistan, where the husband either pays a small fine or undergoes a short period of imprisonment. ${ }^{44}$ The Draft Bill indicates that each wife in a polygynous Muslim marriage can insist on just and equal treatment between wives, and that failure by the husband to do so provides a wife with valid grounds for divorce. ${ }^{45}$ It remains to be seen whether clause 8 will be able to provide sufficient redress to a wife who does not want to be divorced, but, because she prefers to be in a monogamous relationship, refuses to stay with her husband or have conjugal (sexual) relations with him. Such a situation would be unacceptable to traditional Islamic law. ${ }^{46}$

Cognisant that polygyny in Islam can be interpreted to embody gender inequality, and be seen to be oppressive to wives, the Draft Bill places restrictions on polygynous marriages, and although inclining towards establishing equality, it is not equality per se but equality in terms of status, human dignity and equal treatment that can be insisted upon. ${ }^{47}$ As was indicated earlier, the Qur'an itself acknowledges that the achievement of equal treatment and justice in such marriages is virtually impossible. ${ }^{48}$

While issues of MPL and Muslim marriages in particular have received considerable positive attention in decisions of the courts, the judiciary believes that it is the role of the legislature to resolve the complexities surrounding the recognition of Muslim marriages following the work of the SALRC in this regard.

44 See $\mathrm{n} 19$.

45 See $\mathrm{Cl} 1(\mathrm{x})(\mathrm{h})$ of the proposed Draft Bill relating to grounds for divorce.

46 Pearl and Menski Muslim Family Law 178. See also n 71 and 72.

$47 \mathrm{Cl} 3$.

48 See $n 17$. 
The suggested legislation has to date not yet been enacted by Parliament. ${ }^{49}$ Until such time the South African courts remain the main forum for aggrieved Muslim parties to approach when seeking redress for the hardships caused by the non-recognition of the validity of their marriages.

\section{$4 \quad$ The (potential) impact of poligyny on the incidence of HIVIAIDS}

The South African Muslim community is heterogeneous and comprises of cosmopolitan groups consisting of various cultural, ethnic, language and social backgrounds. The 2001 South African Population Census estimates that there are over half a million Muslims (654 064) out of a total population of nearly 45 million. Muslims, therefore, constitute an estimated $1.5 \%$ of the total population compared to the nearly $80 \%$ (36 million) Christians. ${ }^{50}$

Despite the prominence of polygyny as a reason for denying legal recognition to Muslim marriages, it is rarely practised in contemporary South Africa across most race and religious groupings, including Muslims. The 2001 Population Census estimates that a mere $0.1 \%$ (29 469) of the total population (of nearly

49 In the SALRC's 2004/2005 Annual Report it recommended that the Islamic Marriages Bill be introduced when 'circumstances permit'. After having come this far, the Muslim community appears to be split on whether or not they should recognise the Bill. On 22 July 2009, the Constitutional Court, in Women's Legal Centre Trust $v$ President of the RSA (with the United Ulama Council of SA as Amici Curiae) Case CCT 13/09 (2009) ZACC 20, unanimously dismissed an application for direct access to it brought by a women's rights group seeking an order to oblige the President, the Ministers for Justice and Constitutional Development and for Home Affairs, and the principal office-bearers of Parliament to enact legislation regulating Muslim marriages. The Court ruled that the application must procedurally first be lodged in the High Court. The judgment accordingly does not consider whether Parliament may be under an obligation to enact legislation recognising Muslim marriages nor whether such legislation would be consistent with the provisions of the Bill of Rights. See CC 2009 www.constitutionalcourt.org.za/site/Legal-Centre-Trust.htm for the full media summary and judgment. The women's rights group has indicated that it now intends to proceed with its main application (in relation to the recognition of Muslim marriages) in the High Court (Legalbrief Today 2009 www.legalbrief.co.za).

50 See Primary Tables 5.3 (Religion by population group and gender (numbers)) and 5.4 (Religion by population group and gender (percentages)), and Table C (South African population) at StatsSA 2001 www.statssa.gov.za/census01/HTML/RSAPrimary.pdf. Estimated Muslim population breakdown in numbers is as follows: 74701 Black African; 296021 Coloured; 274932 Indian or Asian; and 8410 White. Muslim women number 324 613 and men 329452. 
45 million) over the age of 15 were involved in polygynous marriages. ${ }^{51}$ Muslims mostly come from the Coloured and Indian/Asian population groups, which together account for 1628 of these marriages. Muslim women are estimated by the Population Census to be slightly less in number than Muslim men. The fact that there is not a surplus of Muslim women is a factor that lends support to the view that there appears to be little local social need for polygyny. $^{52}$

South Africa has the sixth highest prevalence of HIV world-wide, with $18.8 \%$ (5.5 million and counting) of the population estimated to be infected. The UNAIDS 2006 Global Report estimated that 320000 South Africans died of AIDS related deaths during 2005. New infections continue to increase with no indications of reaching a natural ceiling. Women are more at risk of infection. On average, three women are infected for every two men infected, the difference being greatest in the 15-24 age group, where three young women are infected for every one young man. ${ }^{53}$ AIDS is a social disease from which Muslims are not exempt. Although the epidemic affects all parts of the population, "[m]any Muslims believe that AIDS is a homosexual ${ }^{54}$ disease or a disease that affects black ${ }^{55}$ people only", ${ }^{56}$ and, like many people, are generally

51 See Primary Tables 6.3 (Marital status amongst those aged 15 years and older by population group and gender (numbers)) and 6.4 (Marital status amongst those aged 15 years and older by population group and gender (percentages)) at StatsSA 2001 www.statssa.gov.za/census01/HTML/RSAPrimary.pdf. Estimated number of polygynous marriages by population breakdown is as follows: 26651 Black African; 1144 Coloured; 484 Indian or Asian; and 1188 White. See text at n 23.

52 See $\mathrm{n} 53$ and $\mathrm{s} 2$.

53 AIDS Foundation [no date] www.aids.org.za/hiv.htm. Although national estimates based on various surveys produce similar figures, the fact that South Africa is such a large and diverse country makes it virtually impossible to know what the real figures are (AVERT 2009 www.avert.org/safricastats.htm). Many people with AIDS remain undiagnosed, either because of fear of stigmatisation or simply because they are in denial that they are at risk. See also text at n 9 and 10. The latest estimates in UNAIDS 2008 data.unaids.org/ indicate that South Africa has the highest AIDS incidence in the world, with an estimated 5.7 million people living with HIV in 2007 (page 214), and an estimated 350000 AIDS related deaths in 2007 (page 217).

54 Although Islam condemns homosexual behaviour (Q.27:54-55; Q.29:28-35), some local Muslims do engage in lesbian and homosexual practices.

55 In terms of the 2001 Population Census (Figure 5) the distribution of the population of South Africa by population group is as follows: Black African (79\%); White (9,6\%); Indian/Asian (2,5\%); and Coloured (8,9\%). Thus, while this perception is not surprising since Black Africans constitute more than three-quarters of the total population, it is, however, true that socio-economic inequalities and political factors have played a big role 
ignorant of the fact that victims of AIDS are not necessarily gay or promiscuous and may have acquired the disease via other means. ${ }^{57}$

Due to the secrecy surrounding HIVIAIDS, Muslims are unwilling to reveal their status while alive and families are afraid to say how their loved ones died. ${ }^{58}$

Although statistics regarding the prevalence of HIV amongst South African Muslims are not readily available, it certainly exists and is on the increase in the Muslim community, including its religious leaders. ${ }^{59}$

Campaigners against HIVIAIDS adopting a health and human rights approach discourage polygyny and blame it for either amplifying rates of HIV transmission or causing its spread. ${ }^{60}$ However, the fact that it is possible for polygyny to be cited as a major risk factor responsible for both spreading and reducing HIV in one country (Malawi), further highlights that there is more at stake here than polygyny as a practice per se. ${ }^{61}$

Some publicly opine that as long as partners, who are HIV-negative, remain faithful to each other within a closed polygynous circle there is no cause for

in poorer Black communities being more vulnerable to HIV infection than other groups (Ahmed (n 6) ii). See $n 53$.

56 Ahmed and Noordien 2001 www.kit.nl/

57 HIV infection is commonly passed on in one of four ways: an infected person has unprotected sex with an uninfected person (HIV is present in sexual (semen and/or vaginal) fluids); from mother to child via pregnancy, birth and breastfeeding; infected blood products (transfusion); or infected drug users' needles. Other routes of HIV transmission include, but are not limited to: donations of semen (artificial insemination); and skin grafts and organ transplants taken from someone who is infected.

58 Ahmed and Noordien 2001 www.kit.nl/

59 Positive Muslims sa www.positivemuslims.org.za/; Ahmed (n 6) 98. 'Positive Muslims' is an organisation formed in the Western Cape in June 2000 to raise awareness, conduct research, and provide support to South African Muslims infected with HIV (Ahmed and Noordien 2001 www.kit.nl/; Ahmed (n 6) 98).

60 Ahmed (n 6) 216-220; Kelly 2006 JJS 1-38. See s 1 above where this approach is elaborated.

61 In a very recent study on polygyny and HIV in Malawi it was found that, other than just the number of formal unions, factors like spousal infidelity (adultery) on the part of both polygynously married men and women and, very interestingly, the selection of women "who are at higher risk of infection (i.e. those who are at higher marriage orders [for example, in a second or third marriage] and those who are widowed compared to divorced)" to join polygynous unions, produces higher HIV prevalence in such unions (Reniers and Tfaily 'Polygyny' 12-13). What was furthermore an interesting feature of the study site, was that the highest prevalence rates were found in a district where polygyny was least common, and vice-versa (where polygyny was most prevalent but HIV infection rates was the lowest) (ibid 6 and 13). 
concern of contracting HIV. Whilst this is true, it is also interesting to note that AIDS transmission via sexual contact is more likely to occur from a male to a female rather than the other way round. ${ }^{62}$ This implies that the prospect of greater infection intra marriage must be present in polygynous marriages if the husband is the infecting party, although nothing precludes a wife, competing with several co-wives for sexual gratification from one husband, from engaging in extra-marital sex with an infected party and so transmitting it to the husband. However, as will be highlighted with hypothetical questions tested on the facts of the Miller case below, it is contended that rather than the institution of marriage itself relating to the disease, it is the conduct of the parties to the marriage relationship, regardless of its nature (polygynous or monogamous).

A case that has gained much publicity in the Western Cape Muslim community was that of a local Muslim woman who had contracted full blown AIDS in a polygynous marriage that lasted seven months. Cognisant of the stigma ${ }^{63}$ that South African Muslims attached to, and the discrimination associated with, the disease, Ms Miller was the first and only Muslim woman in South Africa to have publicly disclosed her status on a Muslim community radio station ${ }^{64}$ in 1996 in an attempt to raise awareness in the community of the fact that Muslims are not exempt from this scourge. Not surprisingly, her disclosure

...was met with mixed feelings as well as denial and often people would state that as a Muslim one could never contract this disease. ${ }^{65}$

It was only in 1995 that she learned that she had contracted the disease from her late Malawian husband who had since died of AIDS. This was her first

62 Page-Shafer 2000 www.thebody.com/. These sources date back to 2000 and 2001, respectively, and, cognisant that knowledge about HIV has vastly increased since then, this position could have changed. In children the virus crosses the placenta to reach the foetus, so that the mother is the likely source of infection.

63 A 1996 masters dissertation on the topic reveals that high levels of HIVIAIDS related stigma were found among Muslims in a Cape Town community "fuelled partly by the belief that HIVIAIDS was not a serious problem among Muslims... Stigma also served as a social barrier to...disclosure of HIV status" (Abrahams Perceptions ii).

64 In South Africa the social stigma attached to HIV, exacerbated by denial and silence, was so huge that, as late as 1998 (barely two years after Ms Miller had gone public about her condition), a Black AIDS activist was murdered because she disclosed her status on public radio.

65 Positive Muslims [no date] www.positivemuslims.org.za/beinghiv.htm. 
marriage and his second. She was also a virgin at the time she married him. She had no prior knowledge that her husband was infected, and he died without knowing that he was infected. ${ }^{66}$

As prescribed by Islam, Ms Miller's first sexual encounter was within a lawful marriage; yet this did not prove to be sufficient to protect her from HIV infection. Did the fact that she was in a polygynous marriage make her particularly more vulnerable to, or at risk of, HIV? She could have been in a monogamous marriage and the husband could have had an extra-marital affair with an infected woman or could have been widowed and infected by his deceased wife? Would the position have been any different if more wives joined the polygynous marriage, with or without the first wife's knowledge?

Would Ms Miller's and her late partner's lives have been different today if they had been in a position to make educated and informed choices, both before engaging in marital sex and during their polygynous marriage? For example, would HIV testing prior to their marriage have: i) influenced their decision to marry each other (if tested HIV-negative) or to reject each other (if tested HIVpositive); ii) prompted them to use condoms to either reduce the risk of, or to prevent the uninfected party from contracting, the disease; and iii) encouraged the infecting party to seek anti-retroviral treatment to prolong his life?

A second or further wife is often aware that she is entering into a polygynous marriage, and may, therefore, give it due consideration before accepting such a proposal. The first wife, whose permission is not required and who has little choice in the matter, is often unaware of the fact that she has become party to such a marriage if it took place clandestinely, and has even less remedies at her disposal. If, however, she is aware of the further marriage and of any potential risk of contracting HIV, she may, for example, insist on the husband's use of condoms, or have recourse to an option of divorce if the marriage contract stipulated against polygyny (which is seldom the case), or even face the prospect of rejection by the husband should she refuse to have sex with 
him $^{67}$ until he provides her with proof of HIV testing ${ }^{68}$ of both himself and the co-wife, who could also potentially already be infected. A right to divorce also offers little comfort to the wife at risk of contracting AIDS.

A Muslim man may lawfully marry up to four wives and divorce them relatively easily. Polygyny was not intended to be used as a status symbol to increase the number of sexual partners or as justification for satisfying the unusual sexual desires of men; which would reduce polygyny to nothing more than a practice which legitimates 'promiscuity' under the guise of marriage. Both parties, presumably, have recourse to the option of divorce if their conjugal needs are not reasonably met.

Inserting clauses in a marriage contract to the effect that the wife would be entitled to divorce her husband should he enter into a polygynous marriage offers little protection to the wife. That Islam permits polygyny is exacerbated by the fact that Islamic divorce laws are interpreted to be particularly stringent, thus placing undue hardship and restrictions on the wife wishing to get out of such a marriage. As far as divorce is concerned, it must be noted that a revocable divorce (raji talaq) is one that does not immediately dissolve the marriage in that it does not become effective until the end of the waiting period (idda), which varies in length, prescribed for the wife. The woman is, therefore, still the legal wife of the husband in this case ${ }^{69}$, and is still obliged to have conjugal relations with him. She, on the other hand, may not remarry until the

67 Conjugal rights are inherent in, and presumed to arise out, of marriage (WLUML ( $n$ 12) 155). Regarding 'sexual access, social practice often demands that the wife make herself available to the husband upon his request' (WLUML (n 12) 156). See n 49.

68 "Muslim law does not accept the possibility of self-imposed chastity and abstinence" (Pearl and Menski (n 42) 178). Nonetheless, 58\% of ulama in the Western Cape who responded to the following question in a survey, "Do you think that the first wife (in a polygynous marriage) has the right to deny conjugal rights to her husband until he produces the results of an Aids test after he marries a second wife?... indicated that the wife does have a right to deny conjugal rights in this situation" (Ahmed (n 6) 218). Cognisant that little over 50\% of the respondents were prepared to adopt an alternative approach to Islamic law to deal with health risks implicit in a modern epidemic, this is nonetheless a step forward and should be welcomed. See also footnote 50 and discussion regarding HIV testing which follows in this section.

Ahmad Muslim law of divorce 82. 
expiry of this period, while her husband may remarry, and have sex, with up to four women at a time.

Since abstinence before marriage is the Islamic norm, early marriage after reaching the age of puberty ${ }^{70}$ is encouraged. While pre-marital and extramarital sex is taboo in Islam, ${ }^{71}$ and its practice more prevalent in non-Muslim societies, this does not mean that local Muslims, who do not live in isolation from the larger non-Muslim society of which they form part, do not engage in such activities. Evidently

[s]ome...Muslim youth are sexually active and engage in pre-marital sex; some adults are promiscuous, engaging in extra-marital sex. ${ }^{72}$

There is also a growing frequency of local 'shotgun' or 'MGM' (must get married) marriages for the sake of covering up a prior pregnancy, ${ }^{73}$ and 'honour deaths $^{14}$ in certain Muslim countries where brothers kill sisters to save the family's good name and honour. Virginity, although prized, is not a prerequisite for marriage. In some countries 'virginity' tests are often sought to prove that the prospective wife is indeed a virgin. It is not uncommon for non-virgins to make a mockery of these tests by having their hymens surgically repaired. While this deceit can be reason enough to terminate such a marriage, sight must not be lost of the fact that being a virgin, although commendable, does not safeguard one from contracting HIVIAIDS, as demonstrated in the Miller case. In South Africa the Children's Act $^{75}$ prohibits virginity testing of children under

70 "...[P]resumed to have been reached by ages 12 for boys and 9 for girls and definitely reached at the completion of the fifteenth year" (Moosa "Women" 20). Islam gives physical maturity precedence over mental preparedness. See also text to $\mathrm{n} 86$.

71 Q.17:32; Q.23:5-7; Q.24:2-3 and Q.70:29-31. There is authoritative Qur'anic commentary to the effect that the Qur'an only sanctions sex within marriage (Asad Message $106 \mathrm{n}$ 26).

72 Dhansay 2002 Treasure Magazine 25. See also Ahmed (n 6) 25-28.

73 Ahmed (n 6) 28.

74 To highlight the extent and seriousness of this topic, the subject of 'honour crimes' or 'crimes of family honour' was the topic of a Project on Strategies of Response to "Crimes of Honour" held in London from 12-13 November 1999. 'Honour crimes' occur in Jordan, Pakistan, Palestine/Israel, Turkey and the United Kingdom (WLUML "Roundtable" 3-33). Act 38 of 2005. 
the age of $16,{ }^{76}$ and in girls older than 16 testing is subject to informed consent. ${ }^{77}$

Notably, a question that was debated and considered by members of the SALRC Project Committee tasked with the recognition of Muslim marriages, was whether or not disclosure of HIVIAIDS status should be legally regulated in a Muslim marriage contract. However, this proved to be too problematic from medical, ${ }^{78}$ constitutional and human rights points of view. ${ }^{79}$ Women's groups have also generally opposed any proposals to introduce partner notification of HIV status. Women are often the first to find out about their status, for example, during a routine pregnancy screening, but are less inclined to disclose such status because of their vulnerability to violence, economic hardship and (social) abandonment. ${ }^{80}$ Not surprisingly, our new Criminal Law (Sexual Offences and Related Matters) Amendment $A c t^{81}$ does not make such non-disclosure an offence. While the legal position remains unchanged, there have been advances in HIV testing which diminish the medical argument. ${ }^{82}$

While there is no legal duty in consensual sexual relationships to disclose one's HIV status to one's sexual partner at any stage during the relationship, it should be encouraged. Together with mutual trust and fidelity between all the parties to a polygynous marriage comes the added safeguard of taking responsibility for each other's health and life.

$76 \mathrm{~S} 12(4)$.

77 S $12(5)$.

78 The disease is divided into four stages: from the window period, where a blood test can prove 'HIV-negative' despite actual infection - to testing HIV-positive despite being healthy with no symptoms - to symptoms only surfacing years later - to full blown aids. See $n 85$.

79 While HIVIAIDS is not explicitly referred to in our Bill of Rights, in terms of s 36(2) "no law may limit any rights entrenched in the Bill of Rights", and in terms of s 14 all persons with HIV have a right to privacy, including privacy concerning their HIV or AIDS status.

80 Albertyn et al "Women's freedom" 379-380.

81 Act 32 of 2007. See Ch 5 of the Act.

82 A local medical expert in the area of HIV testing explained that while older (indirect) HIV testing kits are based on detecting a patient's antibodies to the HIV virus, and that the production thereof may take two to four months (window period), new (direct) HIV testing kits are based on detecting viral antigens which are able to be detected approximately within two weeks after becoming infected. This has reduced the window period significantly. See also Eba (n 6) 22, and n 81. 
Despite the fact that it took its cue from certain Muslim countries which have prescribed a minimum age of marriage for both males and females that is higher than the age of puberty $^{83}$ prescribed by Islamic law, the Project Committee's suggested marital age of 18 was reduced at the insistence of the public. Muslim marriages will now have to comply with the ages and conditions as set out in terms of the South African Marriage Act, ${ }^{84}$ which makes provision for marriages to take place at an earlier age than is the general practice in South Africa. Since early marriage is encouraged in Islam (which promotes physical maturity over mental preparedness), such a reduction in age is preferred over sex outside marriage which is not permitted in Islam but in which some of Muslim youth are engaged. While this can assist in AIDS prevention among the youth, young girls remain a vulnerable social group since they may start to be sexually active before the ages of 15-16 (when their bodies become physically ready for it).

Cultural practices that have no Islamic $^{85}$ legal sanction, but have become intertwined with it, like levirate marriage or "widow inheritance", ${ }^{86}$ also have implicit in them the potential to increase the risk of contracting HIV in polygynous societies. For example, in Muslim Senegal's polygynous society it is not uncommon for a man to marry his brother's widow or widows. ${ }^{87}$ If the brother had died of AIDS, and the man now contracts it from his brother's widow(s), he will spread it to his other wives unless they refuse to have conjugal relations with him. This highlights that polygynous and/or levirate

83 See also $\mathrm{n} 73$ for the Islamic age of puberty.

84 Act 25 of 1961. In terms of s 24 (1) "[n]o marriage officer shall solemnize a marriage between parties of whom one or both are minors unless the consent to the party or parties which is legally required for the purpose of contracting the marriage has been granted and furnished to him in writing". In terms of s 26 (1) '[n]o boy under the age of 18 years and no girl under the age of 15 years shall be capable of contracting a valid marriage except with the written permission of the Minister [of Home Affairs] or any officer in the public service authorized thereto by him...".

85 "O ye who believe!/ Ye are forbidden to inherit /Women against their will..." (Q.4:19). In his Qur'anic commentary on this verse Yusuf Ali writes: "Among many nations, including Arabs in the Days of Ignorance, a step-son or brother took possession of a dead man's widow along with his goods and chattels. This shameful custom is forbidden" (Ali The Holy Qur'an 184 n 527). See also Q.4:22.

86 This occurs when a man dies and his widow is inherited by any of his brothers, or sons from another woman.

87 See Lazaro 2001 www.pbs.org/ 1. Fortunately Senegal has an effective AIDS prevention programme which has helped it stave off an AIDS epidemic (ibid). 
marriages become risk factors when a party is infected with HIV. Fortunately this practice is alien to South African Muslims.

\section{The contribution that Islamic values can make to the fight against AIDS}

In this section the contribution that both an informed approach to HIV, and an enlightened approach to the application of Islamic values could, and would, have on limiting the spread of HIVIAIDS are highlighted.

Many Muslims attribute their contracting of HIV to fate (taqdir). Illness comes from God and must, therefore, be accepted without question. Some even see it as a curse from God, as punishment for sinful behaviour. One of the main findings of a study of perceptions of HIV-related stigma among Muslims in a Cape community was, that

Muslims' religious identity/positioning was the most salient discourse that informed how they understood, made meaning of, and responded to HIVIAIDS. ${ }^{88}$

This highlights that the misperception among Muslims, that they remain unaffected by AIDS because of the protection implicit in Islamic beliefs and tenets, must be influenced by the attitudes and approaches of religious leaders (ulama), whom they hold in high esteem, to the disease.

A hadith exists in which the Prophet says that

whenever promiscuous behaviour dominates a people to such an extent that they display it publicly, there spreads among them invariably, a pestilence the like of which has never been witnessed by their forefathers. ${ }^{89}$

Juxtaposing this insightful predictor into our present day context, many ulama and Muslims believe that abstention from pre-marital and extra-marital sex is a

88 Abrahams (n 64) ii (emphasis added. 89 Ibn Majah as cited in Saabiq:1985. 
true safeguard against AIDS. While such a view is undoubtedly a good starting point, it is not the complete panacea or remedy.

A study, undertaken to determine whether HIV prevalence is lower among Muslims than non-Muslims, found that

\begin{abstract}
[a]mong 38 sub-Saharan African countries, the percentage of Muslims within countries negatively predicted HIV prevalence. [Furthermore] [a] survey of published journal articles containing data on HIV prevalence and religious affiliation showed that six of seven such studies indicated a negative relationship between HIV prevalence and being Muslim. ${ }^{90}$
\end{abstract}

This hypothesis was tested by working from the premise that

[r]eligious constraints on sexuality may have consequences for the transmission of sexually transmitted diseases...[and] [r]ecognising that several Islamic tenets may have the effect, if followed, of reducing the sexual transmission of HIV. ${ }^{91}$

Islamic tenets which guide moral and sexual conduct and which may, if practised/followed, reduce the sexual transmission of AIDS include: reduced age for marriage; no pre-marital sex for both sexes; no extra-marital sex for both sexes; no lesbian and homosexual sex; no prostitution; ritual washing of private parts for both sexes; no sex when the wife is menstruating; male circumcision; and no consumption of alcohol or drug abuse. ${ }^{92}$

Some of these tenets are often enforced in Muslim countries by strict sanctions and harsh punishment. This, however, does not give any guarantee that these tenets are not violated in these countries. Furthermore, in a modern South African context, adherence to these tenets is diminishing among Muslims. It is only by acknowledging the current status quo, and our limitations and fallibility as human beings that we can begin to address the ramifications of this disease. As indicated, Islamic safeguards on their own provide insufficient protection against contracting HIV and must, therefore, be supplemented.

90 Gray 2004 Social Science \& Medicine 1751.

91 Ibid (emphasis added).

92 Ibid 1751-1752. 
Traditional Muslim families tend not to talk openly about and educate their children on sexual matters and related health risks, nor do spouses educate each other on these issues. Avoidance does not lead to immunity, and children, in any event, do learn about these topics at secular schools. Ignorance about HIV, denial, and fear of stigmatisation continue to cloud our judgments. People turn a blind eye, condemn safer sex options, like condoms, (birth control is not enough to prevent HIVIAIDS infection), and pass judgment, all in the name of Islam. Ultimately, casting judgment on the sexual choices of Muslims lie in the domain of God. ${ }^{93}$ The role of ulama, who are well placed to lead, is not to morally alienate, but to engage and guide, their congregations regardless of their sexual lifestyles and sexual orientation, by raising awareness at grassroots level in communities and places of worship about HIVIAIDS and behaviour which might lead to and/or contribute to its spread or reduction.

The Qur'an can, and has been, interpreted to accept, restrict or reject polygyny. Since increasing the number of sexual life partners may potentially increase the risk of acquiring AIDS, polygyny is often the wrong target of AIDS prevention programmes. Blaming this practice for the spread of AIDS can also be dangerous, in that it can create a false sense of security, or an imagined immunity, for those people who do not engage in this practice. Safe sex should be promoted as non-negotiable. Fighting polygyny is not going to do that, because it will not ensure or guarantee that people will behave more responsibly or practise safer sex. It should, therefore, no longer simply be a question of whether polygyny should be permitted or not, but rather whether safer-sex polygyny should be permitted.

In addition to espousing strict moral responsibility, which man by virtue of a sacred trust (amaana) ${ }^{94}$ undertook to bear, Islam places a premium value on self-preservation and safety of the physical body. The reason for this is that not only does the human body contain within it the divine spirit ${ }^{95}$ of God, it is also 
only on loan from God until death. Since sex is life giving, Muslim men and women whilst alive must take every precaution to safeguard their physical health and that of their offspring. HIV can also be transmitted in ways other than through sexual intercourse, and a marital partner may, furthermore, not even be aware that s/he is infected. Thus, trust alone cannot be a sufficient safeguard before engaging in marital sex. Local AIDS statistics show that, although the disease affects all parts of the population, it is women, rather than men, who are more likely to be infected. Islam, furthermore, gives men the added role of being the protectors of women, ${ }^{96}$ which has implicit in it the responsibility for advancing rather than endangering, the physical health of women. A novel rationale for introducing additional safeguards or risk reducing measures which have become necessary in fighting an incurable disease may be found in the balancing of moral responsibility with physical safety. These safeguards/measures include but are not limited to: premarital HIV testing; accessing available health care; utilising available medical treatment; open as opposed to secret polygynous marriages; HIV testing for all parties to a polygynous marriage; condom usage within polygynous marriages if a/ny potential risk of contracting HIV exists or is suspected; condom usage within marriage if extra-marital sex occurs regardless of status; precautions to prevent mother to child infections through pregnancy; and accessing HIV intervention programmes aimed at educating men and vulnerable women and children.

AIDS is both a moral issue and a medical problem. We have to find a balance between the need for practical action and a morally correct approach which promotes tolerance and does not infringe upon human rights. Tradition dictates to Muslims that ultimately the greater good must prevail over evil. Because AIDS does not discriminate between the sexes, its spread cannot be prevented without the full and active participation, and (sexual) empowerment, of both sexes. In order to live healthy, risk free and productive lives, we must not only educate ourselves about the disease, but also be open to seeking creative and novel solutions within the parameters of Islam law.

96 Q.4:34. This verse is deemed to be highly controversial in that it has been interpreted to promote gender inequality. 


\section{Conclusion}

South African Muslims are fortunate to live in a constitutional democracy which upholds the right to freedom of religion and its practice. However, our young democracy has the most severe HIVIAIDS epidemic in the world, and from which Muslims are not immune. In exercising certain sexual choices, Muslims, directly and indirectly, become victims of HIVIAIDS. This modern epidemic, although it has no cure, can certainly be prevented by being proactive and making choices that will lead to prolonging life.

As Muslims we must not let our morality become more uncomfortable and unacceptable than the disease itself. Furthermore, preventing the spread of HIVIAIDS presents a unique opportunity for local Muslims and their religious leaders to adopt novel approaches in finding solutions that are within our reach instead of beyond our grasp.

This article has demonstrated that whilst polygyny may be a contributing factor, it does not cause AIDS to spread any more than monogamy guarantees a reduced spread. While Islam does pave the way for its demise, it is believed that rather than restricting or banning polygyny, which has the potential to create unnecessary resistance, safer sex and open polygynous marriages should be encouraged. Polygyny, in any event, is generally on the decline in South Africa where statistics indicate a limited practice thereof and little social need for its continued practice in the Muslim community. Polygyny should, therefore, be left to die a natural death of its own accord.

Islamic tenets governing sexual conduct and the practice of polygyny, if followed, certainly pave the way to prevent its spread. However, given the current reality in South Africa where local Muslims are, to all intents and purposes, fully integrated into the larger society and, therefore, equally susceptible to its temptations, these tenets must be supplemented with additional safeguards to both promote and sustain change in sexual behaviour. 
An educated and increased awareness of the epidemic in the community, coupled with intervention programmes, will encourage informed sexual choices, and enable parties to positively and responsibly influence each other's sexual choices and behaviour both before and during marriage, and regardless of its (polygynous or monogamous) nature. 


\section{Bibliography}

Abrahams Perceptions

Abrahams S Perceptions of HIVIAIDS-Related Stigma among Muslims in a Cape Town Community (MPsych mini-thesis UWC Bellville 2006)

Ahmad Muslim law of divorce

Ahmad KN The Muslim law of divorce (Kitab Bhavan New Delhi 1984)

Ahmed Positive Muslims

Ahmed AK Positive Muslims: A critical analysis of Muslim Aids activism in relation to women living with HIVIAids in Cape Town (MA thesis UWC Bellville 2003)

Albertyn et al "Women's freedom"

Albertyn C et al "Women's freedom and security of the person" in: Bonthuys E and Albertyn C (eds) Gender, Law and Justice (Juta Cape Town 2007) 295-381

Ali The Holy Qur'an

Ali AY The Holy Qur'an (Text, Translation and Commentary) (Islamic Education Centre Jeddah 1946)

Anon 2002 Treasure Magazine

Anon "Interview with Fagmeeda Miller" 2002 (1) Treasure Magazine 24

Asad Message

Asad M The Message of the Quran (Translation) (Dar al-Andalus London 1980)

Dhansay 2002 Treasure Magazine

Dhansay B "Muslim aids programme raises awareness" 2002 (1) Treasure Magazine 25

Dlamini 1989 CILSA

Dlamini CRM "Should we legalise or abolish polygamy?" 1989 (22)

Comparative and International Law of South Africa 330-345 


\section{Eba "Pandora's box"}

Eba PM "Pandora's box: The criminalisation of HIV transmission or exposure in SADC countries" in Viljoen F and Precious S (eds) Human rights under threat: four perspectives on HIV, AIDS and the law in Southern Africa (Pretoria University Law Press Pretoria 2007) 13-54

Gray 2004 Social Science \& Medicine

Gray PB "HIV and Islam: is HIV prevalence lower among Muslims?" 2004 (58) Social Science \& Medicine 1751-1756

Kaganas and Murray 1991 Acta Juridica

Kaganas F and Murray C "Law, women and the family: the question of polygyny in a new South Africa" 1991 Acta Juridica 116-134

Kelly 2006 JJS

Kelly LM "Polygyny and HIVIAIDS: A health and human rights approach" 2006 (31) Journal for Juridical Science 1-38

Mahomed 1993 SAJHR

Mahomed IA "Legal rights and Aids" 1993 (9) South African Journal of Human Rights vi-ix

Mbatha, Moosa and Bonthuys "Culture and religion"

Mbatha L, Moosa N and Bonthuys E "Culture and religion" in Bonthuys $\mathrm{E}$ and Albertyn C (eds) Gender, Law and Justice (Juta Cape Town 2007)158194

Moosa "Women"

Moosa N "Women, gender and child marriage: Sub-Saharan Africa" in The Encyclopedia of Women and Islamic Cultures Vol 3 (Brill Academic Publishers Leiden 2006) 19-21

Moosa Analysis

Moosa N An Analysis of the Human Rights and Gender Consequences of the New South African Constitution and Bill of Rights with Regard to the Recognition and Implementation Of Muslim Personal Law (MPL) (LLD dissertation UWC Bellville 1996) 


\section{Moosa Comparative Study}

Moosa N A Comparative Study of the South African and Islamic Law of Succession and Matrimonial Property with Especial Attention to the Implications for the Muslim Woman (LLM thesis UWC Bellville 1991)

Moosa Unveiling the mind

Moosa N Unveiling the mind. A herstory of the historical evolution of the legal position of women in Islam (Community Law Centre UWC Cape Town 2004)

Pearl and Menski Muslim Family Law

Pearl D and Menski W Muslim Family Law $3^{\text {rd }}$ ed (Sweet \& Maxwell London 1998)

Rautenbach, Goolam and Moosa "Constitutional analysis"

Rautenbach C, Goolam NMI and Moosa N "Constitutional analysis" in Bekker JC, Rautenbach C and Goolam NMI (eds) Introduction to Legal Pluralism in South Africa $2^{\text {nd }}$ ed (LexisNexis Butterworths Durban 2006) 149-173

Reniers and Tfaily 'Polygyny'

Reniers G and Tfaily R 'Polygyny and HIV in Malawi' Working Paper Institute of Behavioral Science (IBS) Population Program (University of Colorado Boulder 2008) 1-22

Saabiq Fiqh as Sunnah

Saabiq S Fiqh as Sunnah. Kitaab al Zakaah Vol 1 (Dar al Kitab al 'Arabi Beirut Lebanon 1985) 332

Steinberg Three-Letter Plague

Steinberg J Three-Letter Plague. A Young Man's Journey Through a Great Epidemic (Jonathan Ball Johannesburg 2008)

WLUML "Roundtable"

WLUML "Roundtable on Strategies to Address 'Crimes of Honour':

Summary Report" CIMEL/Interights Women Living Under Muslim Laws Occasional Paper No 12 November 2001 London 3-33 
WLUML Knowing Our Rights

WLUML Knowing Our Rights: Women, Family, Laws and Customs in the Muslim World (WLUML London 2003)

\section{Register of legislation}

Childrens Act 38 of 2005

Constitution of the Republic of South Africa 1996

Criminal Law (Sexual Offences and Related Matters) Amendment Act 32 of 2007

Interim Constitution of the Republic of South Africa Act 200 of 1993

Marriage Act 25 of 1961

Muslim Family Laws Ordinance 1961

Recognition of Customary Marriages Act 120 of 1998

Tunisian Law of Personal Status 1956

\section{Register of court cases}

Amod v Multilateral Motor Vehicle Accidents Fund (Commissioner for Gender

Equality Intervening) 1999 (4) SA 1319 (SCA)

Amod v Multilateral Motor Vehicle Accidents Fund 1997 (12) BCLR 1716 (D)

Brown v Fritz Brown's Executors and Others (1860) 3 Searle 313

Daniels v Campbell NO 2003 (9) BCLR 969 (C); 2004 (7) BCLR 735 (CC);

2004 (5) SA 331 (CC)

Davids $v$ The Master 1983 (1) SA 458 (C)

Hassam $v$ Jacobs NO and Others (with the Muslim Youth Movement of South

Africa and the Women's Legal Centre Trust as Amici Curiae) Case CCT

83/08 (2009) ZACC 19

Hassam v Jacobs NO and Others 2008 (4) SA 350 (C)

Ismail v Ismail 1983 (1) SA 1006 (A)

Kalla $v$ The Master 1995 (1) SA 261 (T)

Khan v Khan 2005 (2) SA 272 (T)

Ryland v Edros 1997 (2) SA 690 (C)

Seedat's Executors $v$ the Master (Natal) 1917 AD 302 
Women's Legal Centre Trust v President of the Republic of South Africa and Others (with the United Ulama Council of South Africa and Others as Amici Curiae) Case CCT 13/09 (2009) ZACC 20

\section{Register of internet resources}

Ahmed and Noordien 2001 www.kit.nl/

Ahmed AK and Noordien F 2001 "Positive Muslims" leadership in South

Africa www.kit.nl/exchange/html/2001-3-positive muslim.asp [accessed on 12 June 2008]

AIDS Foundation [no date] www.aids.org.za/hiv.htm

AIDS Foundation South Africa [no date] Human Immunodeficiency Virus www.aids.org.za/hiv.htm [accessed on 10 June 2008]

AVERT 2009 www.avert.org/safricastats.htm AVERT 2009 South Africa HIV and AIDS statistics www.avert.org/safricastats.htm [accessed 16 September 2009]

CC 2009 www.constitutionalcourt.org.za/site/Legal-Centre-Trust.htm Constitutional Court 2009 Media summary www.constitutionalcourt.org.za/site/Legal-Centre-Trust.htm [accessed on 7 September 2009]

CC 2009 www.constitutionalcourt.org.za/site/Hassam.htm

Constitutional Court 2009 Media summary www.constitutionalcourt.org.za/site/Hassam.htm [accessed on 6 September 2009]

Lazaro 2001 www.pbs.org/

Lazaro F de Sam "Senegal's success" 2001 Online NewsHour 17 May 2001 www.pbs.org/newshour/bb/health/jan-june01/aids 5-17.html [accessed 7 September 2009]

Legalbrief Today 2009 www.legalbrief.co.za

Legalbrief Today 2009 Constitutional: Muslim marriage issue must be 
lodged in High Court www.legalbrief.co.za No 236223 July 2009 [accessed 7 September 2009]

Page-Shafer 2000 www.thebody.com/

Page-Shafer K 2000 The global HIVIAIDS epidemic

www.thebody.com/content/world/art2618.html [accessed on 24 June 2008]

Positive Muslims [no date] www.positivemuslims.org.za/

Positive Muslims [no date] HIVIAIDS is not "out there". It is here - Bokaap,

Cravenby, Surrey Estate, Mitchells Plain, Lenasia and Laudium

www.positivemuslims.org.za/ [accessed on 12 June 2008]

Positive Muslims [no date] www.positivemuslims.org.za/beinghiv.htm

Positive Muslims [no date] Being HIV+

www.positivemuslims.org.za/beinghiv.htm [accessed on 12 June 2008]

SALRC 2003 www.law.wits.ac.za/salc/salc.html

South African Law Reform Commission 2003 Report on Islamic Marriages

and Related Matters Project 59 www.law.wits.ac.za/salc/salc.html

[accessed 7 September 2009]

StatsSA 2001 www.statssa.gov.za/census01/HTML/RSAPrimary.pdf

StatsSA 2001 South African Population Census

www.statssa.gov.za/census01/HTML/RSAPrimary.pdf [accessed on 6

September 2009]

UNAIDS 2008 data.unaids.org/

UNAIDS 2008 Global Report data.unaids.org/pub/GlobalReport/2008/jc15

102008 global report pp211 234 en.pdf [accessed 7 September 2009]

\section{List of abbreviations}

art article(s)

ch chapter(s)

par paragraph(s)

S section(s)

MPL Muslim Personal Law 
WLUML Women Living Under Muslim Laws

CEDAW Convention on the Elimination of All Forms of Discrimination Against Women

SALRC South African Law Reform Commission 